\title{
Evaluation of genotoxicity and cytotoxicity, metal ion release induced by metals from orthodontic appliances - An in vivo study
}

\author{
Akhil Shetty ${ }^{1}$, Jubin Baby Abraham², US Krishna Nayak ${ }^{3}$, Ashutosh Shetty ${ }^{4}$, Azhar Mohammed ${ }^{5}$, E. Sneha ${ }^{6 *}$ \\ ${ }^{1}$ Reader, Department of Orthodontics, ${ }^{2}$ Department of Orthodontics, ${ }^{3}$ Principal and Dean, ${ }^{4}$ Professor, ${ }^{5}$ Lecturer, ${ }^{6}$ Department of \\ Orthodontics, A.B.Shetty Memorial Institute of Dental Sciences, India
}

*Corresponding Author:

Email: drsneha2210@gmail.com

\begin{abstract}
Aim: To estimate the concentration of metal ions ( $\mathrm{Ni}, \mathrm{Cr}, \mathrm{Fe}$ and $\mathrm{Co}$ ), cytotoxicity and genotoxicity of buccal mucosal cell in patients being treated with fixed orthodontic appliances.

Materials and Methods: A total of 50 patients aged between 14-30 years of age were included in the study. Three samples of buccal cells were collected from each orthodontic patient at the following times: T (0) - before insertion of the appliance, T (1) 3 months after insertion of the appliance, T (2) - 6 months after insertion of the appliance. Metal ion concentration of buccal cells was evaluated using atomic absorption spectrophotometer (AAS). The buccal cells were also evaluated for genotoxicity (DNA damage) and cytotoxicity (cellular viability) using alkaline comet assay and tryphan blue exclusion dye test respectively.

Results: It was noted that there was a significant $(\mathrm{p}<0.001)$ increase in the metal ion concentrations in the buccal cell sample. The comet assay results showed significant DNA damage in the buccal cells whereas the cellular viability showed a decrease over the study period but the decrease was insignificant.

Conclusion: The buccal mucosa cells of patients treated with fixed orthodontic appliances over a period of six months showed significant increases in nickel, chromium, iron and cobalt content, with significant DNA damage and insignificant decrease in cellular viability. Further studies should be carried out to evaluate the effects of these changes over the course of the treatment.
\end{abstract}

Keywords: Metal Ions, Buccal cells, Cytotoxicity, Genotoxicity

\section{Introduction}

Almost all the fixed metallic orthodontic appliances comprise metals, such as nickel (Ni), chromium $(\mathrm{Cr})$, and cobalt. Apart from withstanding physical, mechanical and biological assaults, a fixed orthodontic set up should also be biocompatible in the oral environment (Bourauel et al.,1998). Metals are not biodegradable, and their sustained release might produce irreversible toxic effects from their accumulation in the tissues. Also, the increased exposure could limit the recovery time needed for cellular repair. Metal toxicity is governed by multiple factors, making it difficult to truly assess the levels that produce cellular damage. The corrosion of an alloy is of fundamental importance to its biocompatibility because the release of elements from the alloy is nearly always necessary for adverse biologic effects such as toxicity, allergy, mutagenicity, and carcinogenicity. Alloy corrosion provides free ions that affect the tissues around it. There is little evidence that elements released from casting alloys contribute significantly to systemic toxicity. The cause of this might be explained by the low release of ions over time. ${ }^{(1)}$

Nickel is a strong immunologic sensitizer, it might activate monocytes and endothelial cells suppressing or promoting the expression of intercellular adhesion molecule-1 (ICAM-1) by endothelial cells depending on ionic concentrations. Nickel complexes in the form of arsenides and sulphides were found to induce DNA alterations, mainly by base damage and site-specific DNA scission. The mutative action of nickel might derive from its effect on inhibiting several enzymes known to restore DNA breaks, promoting microsatellite mutations and increasing total genomic methylation contributing genetic instability. On the other hand chromium and cobalt ions can cause hypersensitivity, dermatitis and asthma. ${ }^{(2)}$

Genotoxicity comprises either mutagenic or carcinogenic processes. Thus, the genotoxic properties of metals from orthodontic appliances are defined as an essential criterion to select these materials in a safe biological manner for patients. ${ }^{(3)}$ The oral mucosa is covered by a stratified epithelium composed of multiple layers of cells that show various patterns of differentiation (or maturation) between the deepest cell layer and the surface. The progenitor cells that cause cell division are situated in the basal layer. The turnover time of the epithelium is the time that it takes for a cell to divide and pass through the entire epithelium. Published data for turnover times for human buccal epithelium have a median value of 14 days. The epithelial stem cells play an important role in preserving the genetic information of the tissues, since the DNA is most vulnerable to damage during mitosis. The genomic damage is produced by environmental exposure to genotoxins, medical procedures (e.g., radiation and chemicals), micronutrient deficiency (e.g., folate), lifestyle factors (e.g., alcohol, smoking, drugs, and stress), and genetic factors such as inherited defects in DNA metabolism or repair. So, it is essential to have a reliable and minimally invasive biomarker to improve the implementation of biomonitoring, diagnostics, and 
treatment of diseases caused by, or associated with, genetic damage. Genotoxicity can be a mutagenic or a carcinogenic process. Yet, no study has reported an association of these conditions with fixed appliances. This could be because normal cells can repair these lesions. But a loss of repair capacity from a reduction in damage detection or an enzymatic deficiency in repair processes might be the initiating event of adverse biologic effects.

The assessment of genotoxic agents can be performed through the application of some wellestablished endpoints such as the micronucleus (MN) frequency, as determined by the $\mathrm{MN}$ assay, or primary DNA damage, as accessed by the comet assay (CA). The CA, which measures single- and/or double-strand breaks in a cell by the cell approach. The CA is considered a quick, simple, sensitive, reliable, and fairly inexpensive way of measuring DNA damage. ${ }^{(4)}$

Because most research on the amounts of metal ions released from orthodontic alloys has shown that they fall below the recommended daily dietary intakes of nickel and chromium, this might be a false assurance of safety, since chronic low levels of metal ions can alter cellular metabolism and morphology, and produce inflammation and even DNA instability. In addition, some in-vivo studies reported biologic toxicity in orthodontic patients. ${ }^{(1)}$ The purpose of this study is to determine the concentrations of these corrosion products in buccal cells and to evaluate the DNA damage induced by them in the mucosal cells.

\section{Materials and Methods}

This study was carried out in the Department of Orthodontics and Dentofacial Orthopaedics A.B Shetty Memorial Institute of Dental Sciences, Mangalore. Buccal mucosal cell preparation was done at the Nitte University Centre for Science Education and Research (NUCSER), K.S. Hegde Medical Academy (KSHEMA), Mangalore. The Research protocol was approved by the Ethical committee of Nitte University, Mangalore. Parent's /patient informed consent was taken for the collection of samples. Spectrometric analysis was done for metal ion concentration in buccal cells which was done at the University Science Instrumentation Centre (USIC), Mangalore University, Mangalore. The buccal cells were evaluated for DNA damage and cellular viability at NUCSER, KSHEMA. This study used buccal cell samples from new patients starting orthodontic treatment. Samples from a total of 50 patients between the age group of 14-30 years were collected. The brackets used were standard stainless steel MBT brackets and arch wire materials used were nickel titanium and stainless steel. The patients were non -smokers, had no previous history of orthodontic treatment and did not use any medicine or supplements. Subjects were thoroughly examined for the absence oral disease, systemic disease, oral restorations or prosthesis. No known allergy to jewellery, watches or any other sources of nickel, chromium, cobalt and iron.

Three samples of buccal cells were collected from each orthodontic patient at the following times: $\mathrm{T}(0)-$ before insertion of the appliance, $\mathrm{T}$ (1) - 3 months after insertion of the appliance, $\mathrm{T}$ (2) -6 months after insertion of the appliance.

Before the study, all subjects were instructed to continue brushing but not use toothpastes and mouthwashes containing chlorhexidine because it has been reported to DNA damage. The buccal mucosal cells were harvested by gentle scrapping of the internal part of the right and left cheeks with a wooden tongue depressor. Gentle scrapings are required to prevent heterogenous cell sample. The depressor were stirred in a $15 \mathrm{ml}$ tube prefilled with $1 \mathrm{ml}$ phosphate buffered solution diluted upto $10 \mathrm{ml}$. Ten strokes on each side of the buccal mucosa was enough to ensure adequate cell density in the suspension. The buccal cell samples were evaluated for cellular viability using tryphan blue exclusion dye test and DNA damage was assessed using alkaline comet assay. Cellular concentrations of $\mathrm{Ni}, \mathrm{Cr}$, $\mathrm{Fe}$ and $\mathrm{Co}$ were assessed using atomic absorption spectrometer.

Cell Viability Assay (Cytotoxicity): The estimation was carried out by following Hartman, et al. method. ${ }^{(5)}$ Centrifuge (Fig. 2) an aliquot of cell suspension being tested for viability $5 \mathrm{~min}$ at $100 \times \mathrm{g}$ and discard supernatant. The size of the aliquot depends on the approximate number of cells present. The aliquot should contain a convenient number of cells to count in a hemocytometer when suspended in $1 \mathrm{ml}$ PBS and then diluted again by mixing with $0.4 \%$ tryphan blue (e.g., $5 \times 105$ cells $/ \mathrm{ml})$. The cell pellet was re-suspended in $1 \mathrm{ml}$ PBS or serum-free complete medium. Serum proteins stain with tryphan blue and can produce misleading results. Determinations must be made in serum-free solution. 1 part of $0.4 \%$ tryphan blueis mixed and 1 part cell suspension (dilution of cells) and allow the mixture to incubate for $3 \mathrm{~min}$ at room temperature. Cells should be counted within 3 to 5 min of mixing with trypan blue, as longer incubation periods will lead to cell death and reduced viability counts. Mixing can be performed in a well of a microtiter plate or a small plastic tube using 10 to $20 \mu \mathrm{l}$ each of cell suspension and trypan blue. A drop of the trypan blue/cell mixture is applied to a hemacytometer and place the hemacytometer on the stage of a binocular microscope and focus on the cells. The unstained (viable) and stained (nonviable) cells are counted separately in the hemacytometer. To obtain the total number of viable cells per $\mathrm{ml}$ of aliquot, multiply the total number of viable cells by 2 (the dilution factor for trypan blue). To obtain the total number of cells per ml of aliquot, add up the total number of viable and nonviable cells and multiply by 2 . 


\section{Calculation:}

Viable cells $(\%)=\underline{\text { Total number of viable cells per } \mathrm{ml}}$ of aliquot x 100

Total number of cells per $\mathrm{ml}$ of aliquot

Evaluation of Genotoxicity (Comet Assay):

The estimation was carried out by following Singh NP et al. method. ${ }^{(6)}$

$400 \mu \mathrm{l}$ of $0.5 \%$ agarose onto a frosted slide at one end and quickly spread by placing a cover slip is placed and slides are kept on ice for instant drying. (This can be done in advance). This is called slide pre coating. 20 $\mu \mathrm{l}$ of buccal cell suspension with $100 \mu \mathrm{l}$ of $0.5 \%$ agaroseis mixed in an eppendorf tube and place onto a pre-coated slide and place the cover slip and allowed to dry for some minutes. Coverslip is then removed and $100 \mu \mathrm{l}$ of $1 \%$ agarose solution is placed onto a slide as a final layer and quickly cover with cover glass. $50 \mu 1$ of trypsin solution is poured onto the gel and cover slip is placed for uniform distribution. It is then kept in Hot air oven maintained at $37^{\circ} \mathrm{C}$ for $30 \mathrm{~min}$. The Cover slip is removed from the slides and the trypsin solution is discarded. $50 \mu \mathrm{l}$ of ice cold Protienase K is poured onto the gel. Cover slip is placed and kept in refrigerator at $0-4^{\circ} \mathrm{C}$ for 1 hour. The Cover glasses are removed and the slides are immersed in lysing solution for overnight in dark at $20^{\circ} \mathrm{C}$. The slides are washed in PBS solution before carrying out Electrophoresis. The slides are then immersed in Electrophoretic buffer for $10 \mathrm{~min}$ in an Electrophoretic unit. The gel slides are then electrophoresed at $12 \mathrm{~V}$ for $18 \mathrm{~min}$. The slides are then taken out of electrophoresis buffer solution and immersed in neutralizing solution for $5 \mathrm{~min}$ at room temperature. Slides were immersed in $1 \mathrm{X} \mathrm{EtBr}$ solution for $1 \mathrm{~min}$ and observed under fluorescent microscope for the presence of comets. The slides are analyzed using fluorescent microscope with a green filter at a magnification of 40X (Fig. 3). Analysis of Comets are done using Comet score software (Fig. 4). The average Tail Length, Tail Area and Olive Tail Movement of the observed is calculated to study the extent of DNA damage in Buccal Mucosa cells.

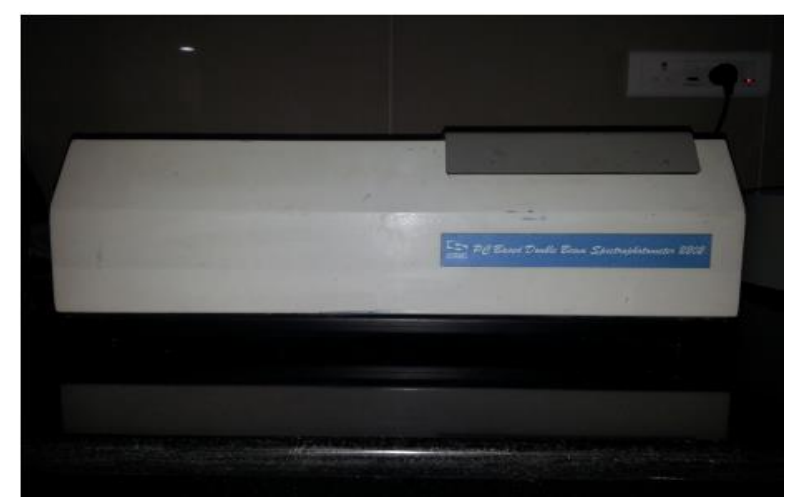

Fig. 1: Atomic Absorption Spectrophotometer

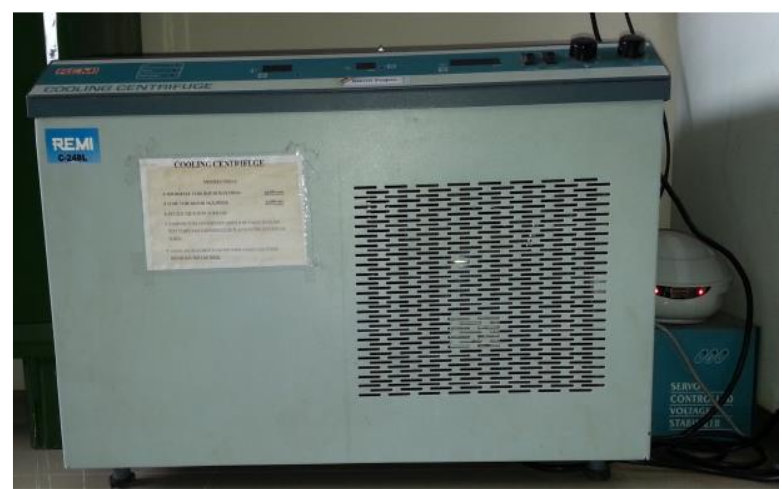

Fig. 2: Centrifuge

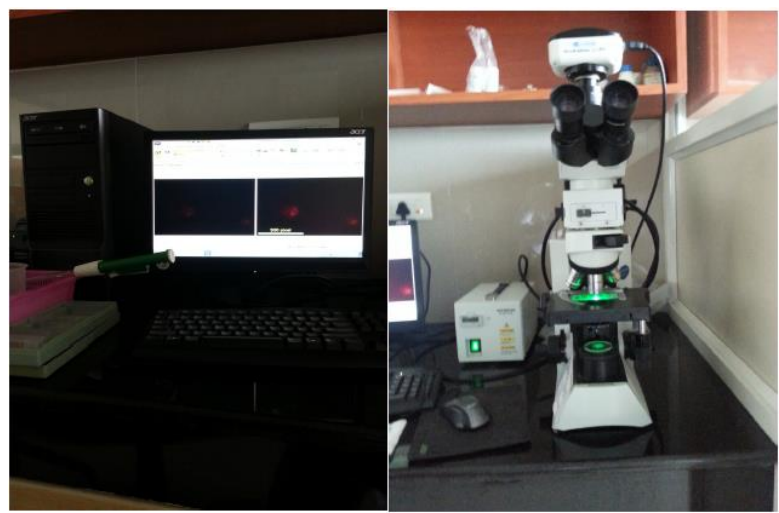

Fig. 3: Fluorescent microscopy with green filter

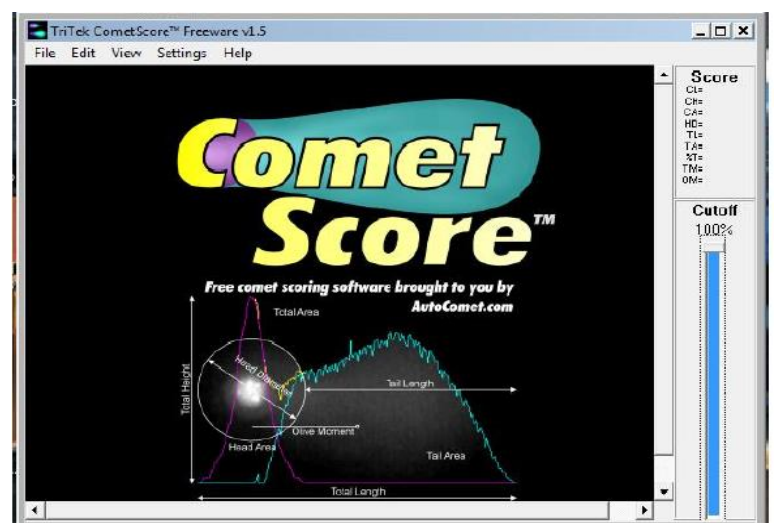

Fig. 4: Comet score software

Statistical Analysis: The following analysis was employed to statistically evaluate the results:

1. Paired t test

2. Tukey's multiple comparison test

The results of the salivary and cellular metal ion concentrations and the comets assay results were statistically evaluated using paired t test. The cellular viability results were evaluated using the Tukey's multiple comparison test. A significance level of p $>0.05$ was considered as statistically insignificant.

\section{Results}

Alkaline Comet Assay: The potential genotoxic effects on metals on buccal mucosa cells were evaluated by 
comet assay, which can show DNA damage. The assay is named for the characteristic shape when the DNA exits the nucleus and the cell body. In this study 3 parameters characterising DNA strand breaks were evaluated: tail length, the percentage of DNA in the tail or tail intensity and tail moment.

Tail length: On examining the results, it was seen that the tail length increased from $\mathrm{T} 0(6.9 \pm 1.2)$ to $\mathrm{T} 2$
$(8.3 \pm 2.5)$. The increase from $\mathrm{T} 0(6.9 \pm 1.2)$ to $\mathrm{T} 1$ $(7.8 \pm 2.4)$ was found to be statistically significant $(\mathrm{p}<0.02)$, whereas the increase from T1 $(7.8 \pm 2.4)$ to T2 $(8.3 \pm 2.5)$ was found to be statistically highly insignificant $(\mathrm{p}=0.2)$. However the increase from T0 $(6.9 \pm 1.2)$ to $\mathrm{T} 2(8.3 \pm 2.5)$ was found to be statistically highly significant $(\mathrm{p}<0.001)$.

\begin{tabular}{|c|c|c|c|c|c|c|c|c|c|}
\hline & \multicolumn{4}{|c|}{ Group } & \multicolumn{4}{|c|}{ Paired differences } & \multirow{2}{*}{$\begin{array}{c}\mathbf{P} \\
\text { value }\end{array}$} \\
\hline & $\begin{array}{c}\% \\
\text { DNA }\end{array}$ & Mean & $\mathbf{N}$ & $\begin{array}{c}\text { Std. } \\
\text { Deviation }\end{array}$ & Mean & $\begin{array}{c}\text { Std. } \\
\text { Deviation }\end{array}$ & $\mathbf{t}$ & df & \\
\hline \multirow[t]{2}{*}{ Pair 1} & T0 & 9.2224 & 49 & 0.81758 & \multirow[t]{2}{*}{-0.57959} & \multirow[t]{2}{*}{2.70678} & \multirow[t]{2}{*}{-1.499} & \multirow[t]{2}{*}{48} & \multirow[t]{2}{*}{0.14} \\
\hline & T1 & 9.802 & 49 & 2.64287 & & & & & \\
\hline \multirow[t]{2}{*}{ Pair 2} & T0 & 9.2224 & 49 & 0.81758 & \multirow[t]{2}{*}{1.12041} & \multirow[t]{2}{*}{1.59569} & \multirow[t]{2}{*}{-4.915} & \multirow[t]{2}{*}{48} & \multirow[t]{2}{*}{$<0.001$} \\
\hline & $\mathrm{T} 2$ & 10.3429 & 49 & 1.30464 & & & & & \\
\hline \multirow[t]{2}{*}{ Pair 3} & $\mathrm{~T} 1$ & 9.802 & 49 & 2.64287 & \multirow[t]{2}{*}{-0.54082} & \multirow[t]{2}{*}{2.95289} & \multirow[t]{2}{*}{-1.282} & \multirow[t]{2}{*}{48} & \multirow[t]{2}{*}{0.206} \\
\hline & $\mathrm{T} 2$ & 10.3429 & 49 & 1.30464 & & & & & \\
\hline
\end{tabular}

Comparison of the mean tail length using paired t test.

Percentage of DNA in tail: On examining the results, it was seen that there was a slight increase of the DNA \% from T0 $(9.2 \pm 0.8)$ to T2 $(10.3 \pm 1.3)$. The increase from T0 $(9.2 \pm 0.8)$ to T1 $(9.8 \pm 2.6)$ was very minor was found to be statistically insignificant $(\mathrm{p}=0.1)$, the increase from T1 $(9.8 \pm 2.6)$ to $\mathrm{T} 2(10.3 \pm 1.3)$ was also found to be statistically insignificant $(\mathrm{p}=0.2)$. However the increase from T0 $(9.2 \pm 0.8)$ to T2 $(10.3 \pm 1.3)$ was found to be statistically highly significant $(\mathrm{p}<0.001)$.

\begin{tabular}{|c|c|c|c|c|c|c|c|c|c|}
\hline & \multicolumn{4}{|c|}{ Group } & \multicolumn{4}{|c|}{ Paired differences } & \multirow{2}{*}{$\begin{array}{c}\mathbf{P} \\
\text { value }\end{array}$} \\
\hline & $\begin{array}{c}\text { Olive Tail } \\
\text { Movement }\end{array}$ & Mean & $\mathbf{N}$ & $\begin{array}{c}\text { Std. } \\
\text { Deviation }\end{array}$ & Mean & $\begin{array}{c}\text { Std. } \\
\text { Deviation }\end{array}$ & $\mathbf{t}$ & df & \\
\hline \multirow[t]{2}{*}{ Pair 1} & T0 & 1.326 & 50 & 0.18273 & \multirow[t]{2}{*}{-0.192} & \multirow[t]{2}{*}{0.24146} & \multirow[t]{2}{*}{-5.623} & \multirow[t]{2}{*}{49} & \multirow[t]{2}{*}{$<0.001$} \\
\hline & $\mathrm{T} 1$ & 1.518 & 50 & 0.16986 & & & & & \\
\hline \multirow[t]{2}{*}{ Pair 2} & T0 & 1.326 & 50 & 0.18273 & \multirow[t]{2}{*}{0.596} & \multirow[t]{2}{*}{0.21089} & \multirow[t]{2}{*}{-19.984} & \multirow[t]{2}{*}{49} & \multirow[t]{2}{*}{$<0.001$} \\
\hline & $\mathrm{T} 2$ & 1.922 & 50 & 0.12002 & & & & & \\
\hline \multirow[t]{2}{*}{ Pair 3} & T1 & 1.518 & 50 & 0.16986 & \multirow[t]{2}{*}{-0.404} & \multirow[t]{2}{*}{0.203} & \multirow[t]{2}{*}{-14.073} & \multirow[t]{2}{*}{49} & \multirow[t]{2}{*}{$<0.001$} \\
\hline & $\mathrm{T} 2$ & 1.922 & 50 & 0.12002 & & & & & \\
\hline
\end{tabular}

Comparison of the mean olive tail moment using paired t test.

Cellular Viability: On examining the cellular viability of the buccal cells, it was observed that the percentage of viable cells decreased from T0 $(18.6 \pm 1.67)$ to T2 $(9.3 \pm 4.21)$. The comparison between the time periods over six months showed that the even though there was a decrease in the percentage of viable cells but it was statistically insignificant $(\mathrm{p}>0.05)$.

\begin{tabular}{|c|c|c|c|c|c|c|}
\hline & \multicolumn{4}{|c|}{ Group } & \multirow{2}{*}{$\begin{array}{l}\text { Paired differences } \\
\text { Tukey's Multiple } \\
\text { Comparison test }\end{array}$} & \multirow{2}{*}{$\begin{array}{c}P \\
\text { value }\end{array}$} \\
\hline & $\begin{array}{c}\text { \% Cellular } \\
\text { Viability }\end{array}$ & Mean & $\mathbf{N}$ & $\begin{array}{c}\text { Std. } \\
\text { Deviation }\end{array}$ & & \\
\hline \multirow[t]{2}{*}{ Pair 1} & T0 & 18.6 & 50 & 1.67 & T0 & \multirow[t]{2}{*}{$>0.05$} \\
\hline & $\mathrm{T} 1$ & 17.4 & 50 & 6.31 & $\mathrm{~T} 1$ & \\
\hline \multirow[t]{2}{*}{ Pair 2} & T0 & 18.6 & 50 & 1.67 & T0 & \multirow[t]{2}{*}{$>0.05$} \\
\hline & T2 & 9.3 & 50 & 4.21 & $\mathrm{~T} 2$ & \\
\hline \multirow[t]{2}{*}{ Pair 3} & T1 & 17.4 & 50 & 6.31 & T1 & \multirow[t]{2}{*}{$>0.05$} \\
\hline & $\mathrm{T} 2$ & 9.3 & 50 & 4.21 & $\mathrm{~T} 2$ & \\
\hline
\end{tabular}

Comparison of the mean \% cellular viability using Tukey’s multiple comparison test.

Cellular Concentrations of Metal Ions Nickel: On examining the concentration of nickel in buccal cells over a period of six months, it was seen that the concentrations increased from T0 (21.9 $\pm 1.1 \mathrm{ppb})$ to T2 (26.9 $\pm 1.1 \mathrm{ppb})$. The 
results showed a statistically highly significant $p$ value $(p<0.001)$ when cellular concentrations were compared at different time intervals with each other.

\begin{tabular}{|c|c|c|c|c|c|c|c|c|c|}
\hline & \multicolumn{4}{|c|}{ Group } & \multicolumn{4}{|c|}{ Paired differences } & \multirow{2}{*}{$\begin{array}{c}P \\
\text { value }\end{array}$} \\
\hline & $\begin{array}{c}\text { Salivary } \\
\text { nickel }\end{array}$ & Mean & $\mathbf{N}$ & $\begin{array}{c}\text { Std. } \\
\text { Deviation }\end{array}$ & Mean & $\begin{array}{c}\text { Std. } \\
\text { Deviation }\end{array}$ & $\mathbf{t}$ & df & \\
\hline \multirow[t]{2}{*}{ Pair 1} & T0 & 21.978 & 50 & 1.17583 & \multirow[t]{2}{*}{-1.44} & \multirow[t]{2}{*}{2.05198} & \multirow[t]{2}{*}{-4.962} & \multirow[t]{2}{*}{49} & \multirow[t]{2}{*}{$<0.001$} \\
\hline & $\mathrm{T} 1$ & 23.418 & 50 & 1.56384 & & & & & \\
\hline \multirow[t]{2}{*}{ Pair 2} & T0 & 21.978 & 50 & 1.17583 & \multirow[t]{2}{*}{-4.94} & \multirow[t]{2}{*}{1.76601} & \multirow[t]{2}{*}{$\begin{array}{l}-19.78 \\
\end{array}$} & \multirow[t]{2}{*}{49} & \multirow[t]{2}{*}{$<0.001$} \\
\hline & $\mathrm{T} 2$ & 26.918 & 50 & 1.15382 & & & & & \\
\hline \multirow[t]{2}{*}{ Pair 3} & $\mathrm{~T} 1$ & 23.418 & 50 & 1.56384 & \multirow[t]{2}{*}{-3.5} & \multirow[t]{2}{*}{1.94044} & \multirow[t]{2}{*}{-12.754} & \multirow[t]{2}{*}{49} & \multirow[t]{2}{*}{$<0.001$} \\
\hline & $\mathrm{T} 2$ & 26.918 & 50 & 1.15382 & & & & & \\
\hline
\end{tabular}

Comparison of the mean cellular nickel ion concentration using paired $t$ test.

Chromium: On examining the concentration of chromium in buccal cells over a period of six months, it was seen that the concentrations increased from $\mathrm{T} 0(20 \pm 1.1 \mathrm{ppb})$ to $\mathrm{T} 2(22.7 \pm 1.2 \mathrm{ppb})$. A statistically significant increase was observed between $\mathrm{T} 0$ and $\mathrm{T} 1$. The comparison between $\mathrm{T} 1$ and $\mathrm{T} 2$, T0 and $\mathrm{T} 3$ showed a statistically highly significant $\mathrm{p}$ value $(\mathrm{p}<0.001)$.

\begin{tabular}{|c|c|c|c|c|c|c|c|c|c|}
\hline & \multicolumn{4}{|c|}{ Group } & \multicolumn{4}{|c|}{ Paired differences } & \multirow{2}{*}{$\begin{array}{c}P \\
\text { value }\end{array}$} \\
\hline & $\begin{array}{c}\text { Salivary } \\
\text { chromium }\end{array}$ & Mean & $\mathbf{N}$ & $\begin{array}{c}\text { Std. } \\
\text { Deviation }\end{array}$ & Mean & $\begin{array}{c}\text { Std. } \\
\text { Deviation }\end{array}$ & $\mathbf{t}$ & df & \\
\hline \multirow[t]{2}{*}{ Pair 1} & T0 & 20.082 & 50 & 1.16841 & \multirow[t]{2}{*}{-0.784} & \multirow[t]{2}{*}{1.90695} & \multirow[t]{2}{*}{-2.907} & \multirow[t]{2}{*}{49} & \multirow[t]{2}{*}{0.005} \\
\hline & $\mathrm{T} 1$ & 20.866 & 50 & 1.2295 & & & & & \\
\hline \multirow[t]{2}{*}{ Pair 2} & T0 & 20.082 & 50 & 1.16841 & \multirow[t]{2}{*}{-2.62} & \multirow[t]{2}{*}{1.69537} & \multirow[t]{2}{*}{-10.928} & \multirow[t]{2}{*}{49} & \multirow[t]{2}{*}{$<0.001$} \\
\hline & $\mathrm{T} 2$ & 22.702 & 50 & 1.26499 & & & & & \\
\hline \multirow[t]{2}{*}{ Pair 3} & $\mathrm{~T} 1$ & 20.866 & 50 & 1.2295 & \multirow[t]{2}{*}{-1.836} & \multirow[t]{2}{*}{1.73073} & \multirow[t]{2}{*}{-7.501} & \multirow[t]{2}{*}{49} & \multirow[t]{2}{*}{$<0.001$} \\
\hline & $\mathrm{T} 2$ & 22.702 & 50 & 1.26499 & & & & & \\
\hline
\end{tabular}

Comparison of the mean cellular chromium ion concentration using paired $t$ test.

Iron: On examining the concentration of iron in buccal cells over a period of six months, it was seen that the concentrations greatly increased from T0 $(37.6 \pm 1.9 \mathrm{ppb})$ to T2 $(86.3 \pm 2.7 \mathrm{ppb})$. The results showed a statistically highly significant $\mathrm{p}$ value $(\mathrm{p}<0.001)$ when cellular concentrations were compared at different time intervals with each other.

\begin{tabular}{|c|c|c|c|c|c|c|c|c|c|}
\hline & \multicolumn{4}{|c|}{ Group } & \multicolumn{4}{|c|}{ Paired differences } & \multirow{2}{*}{$\begin{array}{c}\mathbf{P} \\
\text { value }\end{array}$} \\
\hline & $\begin{array}{c}\text { Salivary } \\
\text { iron }\end{array}$ & Mean & $\mathbf{N}$ & $\begin{array}{c}\text { Std. } \\
\text { Deviation }\end{array}$ & Mean & $\begin{array}{c}\text { Std. } \\
\text { Deviation }\end{array}$ & $\mathbf{t}$ & df & \\
\hline \multirow[t]{2}{*}{ Pair 1} & T0 & 37.652 & 50 & 1.99082 & \multirow[t]{2}{*}{-16.71} & \multirow[t]{2}{*}{2.7824} & \multirow[t]{2}{*}{-42.466} & \multirow[t]{2}{*}{49} & \multirow[t]{2}{*}{$<0.001$} \\
\hline & T1 & 54.362 & 50 & 1.93189 & & & & & \\
\hline \multirow[t]{2}{*}{ Pair 2} & T0 & 37.652 & 50 & 1.99082 & \multirow[t]{2}{*}{-48.742} & \multirow[t]{2}{*}{3.21051} & \multirow[t]{2}{*}{-107.353} & \multirow[t]{2}{*}{49} & \multirow[t]{2}{*}{$<0.001$} \\
\hline & $\mathrm{T} 2$ & 86.394 & 50 & 2.75936 & & & & & \\
\hline \multirow[t]{2}{*}{ Pair 3} & T1 & 54.362 & 50 & 1.93189 & \multirow[t]{2}{*}{-32.032} & \multirow[t]{2}{*}{3.23068} & \multirow[t]{2}{*}{-70.109} & \multirow[t]{2}{*}{49} & \multirow[t]{2}{*}{$<0.00$} \\
\hline & $\mathrm{T} 2$ & 86.394 & 50 & 2.75936 & & & & & \\
\hline
\end{tabular}

Comparison of the mean cellular iron ion concentration using paired t test.

Cobalt: On examining the concentration of cobalt in buccal cells over a period of six months, it was seen that the concentrations greatly increased from $\mathrm{T} 0(3 \pm 0.63 \mathrm{ppb})$ to $\mathrm{T} 2(4.1 \pm 0.5 \mathrm{ppb})$. The results showed a statistically highly significant $\mathrm{p}$ value $(\mathrm{p}<0.001)$ when cellular concentrations were compared at different time intervals with each other.

\begin{tabular}{|l|l|c|c|c|c|c|c|c|c|}
\hline & \multicolumn{4}{|c|}{ Group } & \multicolumn{3}{c|}{ Paired differences } & \multirow{2}{*}{ P } \\
\cline { 2 - 10 } & $\begin{array}{c}\text { Salivary } \\
\text { cobalt }\end{array}$ & Mean & $\mathbf{N}$ & $\begin{array}{c}\text { Std. } \\
\text { Deviation }\end{array}$ & Mean & $\begin{array}{c}\text { Std. } \\
\text { Deviation }\end{array}$ & $\mathbf{t}$ & df & value \\
\hline Pair 1 & T0 & 3.002 & 50 & 0.63229 & -0.616 & 0.82322 & -5.291 & 49 & $<0.001$ \\
\cline { 2 - 10 } & T1 & 3.618 & 50 & 0.57096 & & & & & \\
\hline Pair 2 & T0 & 3.002 & 50 & 0.63229 & -1.134 & 0.86958 & -9.221 & 49 & $<0.001$ \\
\hline
\end{tabular}




\begin{tabular}{|l|l|l|l|l|l|l|l|l|l|}
\hline & T2 & 4.136 & 50 & 0.5989 & & & & & \\
\hline \multirow{2}{*}{ Pair 3 } & T1 & 3.618 & 50 & 0.57096 & -0.518 & 0.83169 & -4.404 & 49 & $<0.001$ \\
\cline { 2 - 10 } & T2 & 4.136 & 50 & 0.5989 & & & & & \\
\hline
\end{tabular}

Comparison of the mean cellular cobalt ion concentration using paired $t$ test.

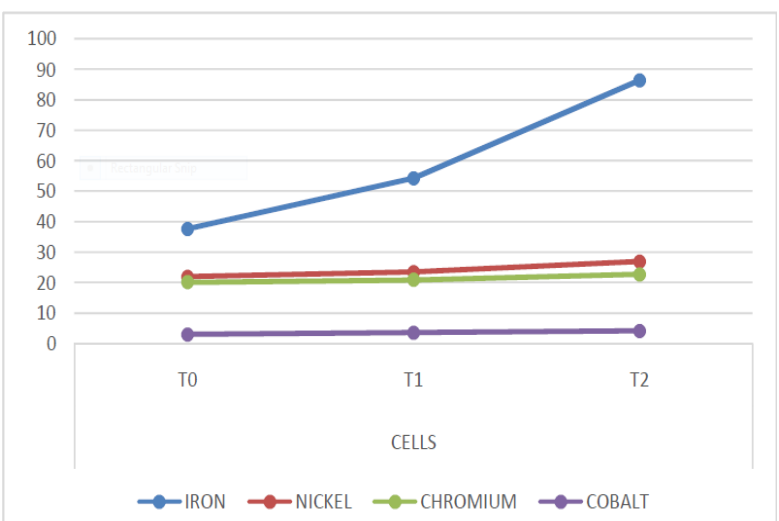

Representation of mean metal ion concentration in buccal mucosal cells at various.

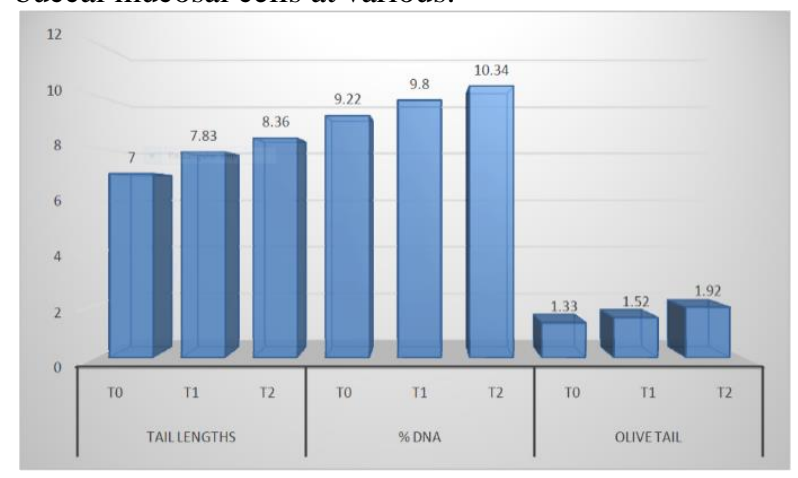

Time intervals

Representation of the mean tail length, \% DNA and Olive Tail Moment of the alkaline comet assay at various time intervals.

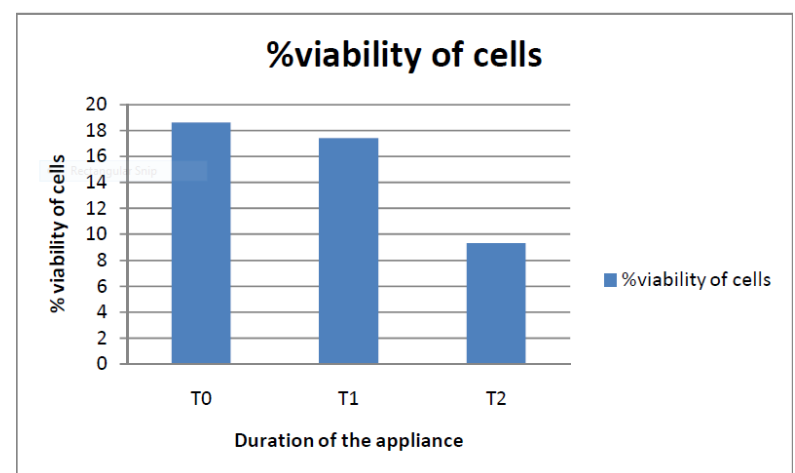

Representation of mean \% viability of cells at various time intervals.

\section{Discussion}

To evaluate the cytotoxicity, genotoxicity and metal ion release induced by metals of fixed orthodontic appliances on buccal mucosal cells, a longitudinal clinical investigation was carried out for 6 month period. This study also evaluated the effects of the corrosive by products produced by the orthodontic appliances present in the oral cavity on the buccal mucosal cells of the treated patients. Evaluation of these by products in saliva might have limitations, as the saliva is continuously washed and swallowed, and will give information at the moment of sampling only. Whereas in the case of buccal cells, the orthodontic appliances are in continuous contact with it and studies have reported that oral tissues take uptake the metal ions released by adjacent metal restorations. ${ }^{(1)}$

The metal ions evaluated in this study have carcinogenic and mutagenic capabilities, so the cytotoxic and genotoxic effects as well as the cellular concentrations of metal ions in the buccal cells were evaluated in the study.

In some orthodontic patients, allergy has been a documented reaction. Although a problem, the true concern should be the possible cytotoxicity or, even more importantly, the genotoxicity of orthodontic appliances. Persistent DNA damage can lead to mutations. In a labile tissue such as the buccal mucosa, cellular proliferation of a damaged cell might cause many defective cells. Cellular toxicity will also affect the cells' metabolism and, in turn, their function and repair capacity. ${ }^{(1)}$

Cytotoxicity was denoted by a significant decrease in cellular viability. Cellular viability at $\mathrm{T} 0$ in the treatment group was high. When compared with the T0 value, the viability decreased significantly at $\mathrm{T} 2$. Faccioni et al.,(2003) reported similar cytotoxicity for the treated group in their study, when the cellular viability decreased significantly ${ }^{(7)}$ Other in vivo studies by Kasacka et al,.(2006) and Pereira et al.,(2009) have reported decreases in cellular viability and metabolism in orthodontic patients. ${ }^{(8,9)}$ Cellular alterations included changes in metabolism, alterations in the regularity of cells, increases in the cellular nuclear-cytoplasmic area ratio, and larger cells with pyknotic and vacuolated nuclei. ${ }^{(1)}$ Although a decrease in cellular viability was observed, on statistical analysis it was found to be insignificant.

Several in vitro and in vivo methods have been used to study the release of metals and their content in biologic fluids, including saliva, blood, and urine. The studies have shown that these metals were released during the first 4 or 5 months of orthodontic therapy, and the metals were actually absorbed by patients with systemic distribution. The main conclusions indicate that the measurable amount of metal, released from orthodontic appliances in saliva or blood samples, was significantly below the average dietary intake and did not reach toxic concentrations. Although the 
orthodontic appliances had no effect on the general levels of metals, it cannot be excluded that even nontoxic concentrations might be sufficient to induce important biologic effects in cells of oral mucosa. Even if a genotoxic potential has been demonstrated in certain systems, the mechanisms underlying this feature are largely unknown, but several possible pathways seem to be involved, such as the interaction of metals with DNA (crosslinks), the generation of oxidative DNA damage, or interference with DNA repair and replication processes. ${ }^{(7)}$

On evaluation of the comet assay for the genotoxic effects in the buccal mucosa, it was observed that DNA damage increased from $\mathrm{T} 0$ to $\mathrm{T} 2$ after evaluation of all the parameters of the assay (\%DNA, tail length and olive tail moment) and was found to be statistically significant $(\mathrm{p}<0.001)$. The result obtained were in accordance to the studies done by $\mathrm{Hafez}$ et al.,(2011) ${ }^{(2)}$ and Faccioni et al.,(2003). ${ }^{(8)}$ Westphalen et al $(2008)^{(3)}$ also recorded DNA damage in their orthodontic patients at 30 days of treatment with the micronucleus test. However, the comet assay showed insignificant changes.

The cellular concentrations of the metal ions $(\mathrm{Ni}$, $\mathrm{Cr}, \mathrm{Fe}$ and $\mathrm{Co}$ ) also showed an increase from the time intervals $\mathrm{T} 0$ to $\mathrm{T} 2$ and were statistically significant $(\mathrm{p}<0.001)$. This increase in the metal ions concentrations in the buccal cells can related to the studies to the by Hafez et al.,(2011) $)^{(2)}$ and Faccioni et al.,(2003). ${ }^{(8)}$ However Amini et al.,(2008) reported that the increase of only $\mathrm{Ni}$ was significant, and that of $\mathrm{Cr}$ and Co were insignificant. So it is seen that even though there is an increase in metal ion concentrations $(\mathrm{Ni}, \mathrm{Cr}, \mathrm{Fe}$ and $\mathrm{Co})$ which was seen over the study period, these values were well within the normal limits and none of the metal ion concentrations reached toxic levels.

This study showed significant changes occurring in orthodontic patients treated with fixed appliances over a 6-month period. These changes included increases in cellular nickel, chromium, iron and cobalt content, decreases in cellular viability, and evidence of DNA damage. The fate of these changes needs follow-up, since repair of biologic changes is possible. When DNA damage occurs, various reparative mechanisms are regularly activated to maintain the integrity of the DNA. However, the persistence of DNA damage will lead to genetic instability and DNA mutations. It is documented that metal ions interfere with many protective and reparative pathways that maintain cellular homeostasis and DNA integrity. Based on the recorded biologic changes, it would be prudent to reduce any insult induced by the orthodontic appliances. This can be achieved by the adoption of treatment techniques that reduce the duration of treatment and the enforcement of higher standards for corrosion resistance of orthodontic appliance by the manufacturers. ${ }^{(1)}$

\section{Conclusion}

1. The buccal mucosa cells of patients treated with fixed orthodontic appliances over a period of six months showed significant increases in nickel, chromium, iron and cobalt content, with significant DNA damage and insignificant decrease in cellular viability.

2. Further studies should be carried out to evaluate the effects of these changes over the course of the treatment.

\section{References}

1. 1.Hend Saleh Hafez, Essam Mohammed Nassef Selim, Faten Hussein Kamel Eid, Wael Attia Tawfik, Emad A. Al- Ashkar, And Yehya Ahmed Mostafa. Cytotoxicity, genotoxicity and metal release in patients with fixed orthodontic appliances: A longitudinal in vivo study. Am J Orthod Dentofacial Orthop 2011;140:298-308.

2. Evangelia Petoumenou, Martin Arndt, Ludger Keilig, Susanne Reimann, Hildegard Hoederath, Theodore Eliades, Andreas Jäger, and Christoph Bourauelf. Nickel concentration in the saliva of patients with nickeltitanium orthodontic appliances. Am J Orthod Dentofacial Orthop 2009;135:59-65.

3. G.H. Westphalen, L.M. Menezes, D. Prá, G.G. Garcia, V.M. Schmitt, J.A.P. Henriques and R. Medina-Silva. In vivo determination of genotoxicity induced by metals from orthodontic appliances using micronucleus and comet assays. Genetics and Molecular Research 2008;7(4):1259-1266

4. Fariborz Amini, Alireza Jafari, Parviz Amini and Sepehr Sepasi. Metal ion release from fixed orthodontic appliances - an in vivo study. European Journal of Orthodontics 2012;34:126-130.

5. Hartmann A, Speit G. The contribution of cytotoxicity to DNA- effects in the single cell gel test comet assay. Toxicol Lett 1997;90:183-188.

6. Singh NP, McCoy MT, Tice RR, Schneider EL. A simple technique for quantitation of low levels of DNA damage in individual cells. Exp Cell Res 1998;175(1):184-91.

7. Fiorenzo Faccioni, DDS, MD, Paola Franceschetti, PhD, Marzia Cerpelloni, TA, and Maria E. Fracasso. In vivo study on metal release from fixed orthodontic appliances and DNA damage in oral mucosa cells. Am J Orthod Dentofacial Orthop 2003;124:687-94.

8. Sandin B, Chorot P. Changes in skin, salivary, and urinary $\mathrm{pH}$ as indicators of anxiety level in humans. Psychophysiology 1985;22:226-230.

9. Kasacka I, Szarmach IJ, Buczko P, Tankiewicz A, Pawlak D. Preliminary evaluation of morphological parameters of the saliva in patients undergoing orthodontic treatment. Adv Med Sci 2006; 51(Suppl 1):52-4. 